\title{
Service Quality as Moderator in the Relationship between Experience and Value
}

\author{
Kwok See Ying \\ University Technology of Malaysia \\ E-Mail: s.ying0525@yahoo.com \\ Ahmad Jusoh \\ University Technology of Malaysia \\ E-Mail: ahmadj@fppsm.utm.my \\ Zainab Khalifah \\ University Technology of Malaysia \\ E-Mail: m-zainab@utm.my
}

\begin{abstract}
Tourism is a fast-growing business that receives global attention. Statistical data revealed that the worldwide enormous growth of tourism industry and tourism itself are predicted to be significant contributors to the future economic development. Research in the tourism industry will contribute to the development of new theories in management, sociology and economics fields. In addition, the findings of the research will provide input in planning economic activities. Malaysia, like many other countries is experiencing rapid growth in its tourism industry. However, it is clear that the issue of tourist value upon local tourism industry does not receive much attention from researchers compared to other service industries such as telecommunication, education, and other. Therefore, a better understanding on the value of tourism and its related antecedent factors in the context of local tourism is crucial. The review on related literature has shown that there is a direct relationship between service quality and value, as well as between experience and value. Even though previous researches have proven that, there is direct relationship between service quality and value, this study will focus on testing whether the service quality will moderate the relationship between experience and value. Therefore, the discussion in this paper will portray how service quality is able to enhance the relationship between experience and value.
\end{abstract}

Keywords: Value, Experience, Service Quality 


\section{INTRODUCTION}

The ultimate goal of most service provider is to provide high value services and products to the customers. Literature review has proven that value is the driver to satisfaction level (Andreassen and Lindestad, 1998; Chen, 2008; Patterson and Spreng, 1997; Ryu et al., 2008). Hence, study to further understand value creation is important. Accordingly, the study related to value has continuously gain attention from social science researchers and academics. As value is dynamic in nature, more research need to be carried out to have better understanding in the dimensions of value. In relation to value, some factors might affect value creation, such as quality (Bojanic, 1996; Duman and Mattila, 2005; Kashyap and Bojanic, 2000; Oh, 2000; Chang and Wildt, 1994; Lai et al., 2009), price (Bojanic, 1996; Duman and Mattila, 2005; Kashyap and Bojanic, 2000; Oh, 2000; Chang and Wildt, 1994; Lai et al., 2009), and experience (Pine and Gilmore, 1999). Based on the interpretation of utility theory, quality will positively manipulate value, while price will offset the value (Duman and Mattila, 2005; Chang and Wildt, 1994; Lai et al., 2009). Hence, quality is an important factor in the study on value. Moreover, Pine and Gilmore (1999) have made an indication on the importance in engaging customer through experience for value creation rather than just serving them. Thus, by including experience in the discussion, the explanation of value creation could be enhanced.

Past studies have explained some relationship model of constructs between both service quality to value (Andreassen and Lindestad, 1998; Lai et al., 2009), and experience to value (Chen, 2007; Chen and Chen, 2010; Hume and Mort, 2008). However, the relationship between service quality and experience has not received proper attention from previous researchers. Hence, it is important to study the comprehensive relationship between these three constructs, because we believed that instead of a direct influence, there might be an interaction between service quality and overall experience towards value creation. Analysis of the literature provides a basis for the development of a theoretical framework to understand how these variables are interacted.

Studies on value creation have been carried out across industries. However, the study on the related factors that creates values in tourism sector is relatively fewer than in other service industries such as telecommunication, education and other. Statistical data shown by World Tourism Organization have revealed that the enormous growth of worldwide tourism industry, thus it is predicted that tourism will be a significant economic contributor especially to the tourism-based countries. Therefore, the study on the related factors that creates value is not only significant theoretically but also has implications on the economy as a whole. 


\section{CONCEPTS AND DEFINITION}

"Tourism comprises the activities of persons, travelling to and staying in places outside their usual environment for not more than a consecutive year for leisure, business and other purpose" (UNWTO, 1995, p. 12). Several characteristics were found to be similar based on the analysis on the definition of tourism from different perspectives. The characteristics include movement, overnight stay, short-term, not usual environment, having purpose and engaging in activities of travelling (UNWTO, 1995; McIntosh et al., 1995; Horner and Swarbrooke, 1996).

There are three major constructs in this study, the predictor variable is experience, the criterion variable is value, and the specification variable is service quality. Value is the consumer's overall assessment on perceptions of what is received and what is given (Zeitheml, 1988). McDougall and Levesque defined value as "benefits received relative to costs" (McDougal and Levesque, 2000, p. 393). In short, value can be viewed as the difference between perceived benefits and costs (Zeitheml, 1988; Holbrook, 1994), or the overall sacrifices incurred in comparison benefits (Buzzell and Gale, 1987; Monroe, 1991) received by the tourists during the trip (Vargo and Lusch, 2004).

Experience refers to the collection point in which one party exchanges sensory stimuli, information, and emotion (Robinnette et al., 2001) after engaged in certain activities. Gupta and Vajic (1999) also defined service experience as all of the sensation or knowledge acquisition resulting from interaction with different elements created by service providers. Besides that, Sandström et al. believed that experiences can be enjoyed by any type of consumers through the consumption of any type of products and services (Sandström et al., 2008; Zeithaml et al., 2006). In short, experience is the tourists' internal responses of the trip.

Service quality refers to the conformance to the customer requirements of the service delivered (Chakrabarty et al., 2007). Generally, it is widely accepted that service quality is dependent on the degree in which actual service performance meets customer needs and expectations (Presbury et al., 2005; Asher, 1996; Grönroos, 1990). In brief, service quality is referring to the tourist's judgment on the service received during the trip. 


\section{THEORETICAL BACKGROUND AND PAST RESEARCH}

Value always refer to the trade-off between perceived costs and benefits (Zeitheml, 1988; Holbrook, 1994). In addition, Vargo and Lusch (2004) have stressed that value requires participation, whereby value is realized when a service is consumed (Vargo and Lusch, 2004). To further enhance the meaning, they stated that value is used as the evaluation of the service experience, that is the individual judgment on the total sum of all the functional and emotional outcome of the service experience (Vargo and Lusch, 2004).

The ways in which customers experience an activity is critical to their perception of value (Bitner, 1992). To highlight that, Orsingher and Marzocchi (2003) have indicated that experience is a dimension related to perceived value. In addition, the studies on value chain management suggested that every point in the experience may have the potential of creating value to the customer (Ron, 1992). Values created from each experience point will sum up as the overall perceived value. Therefore, the value chain studies have supported that value is affected by the experience encountered.

Value increases when the perceived services are positive (Fiore and Kim, 2007). Therefore, the experience itself will affect the assessment on the overall service encountered. Research indicated that the experience encountered during the service would directly influence the benefits gained (Prentice et al., 1998), which in return will significantly affect the perceived value. Furthermore, previous studies have empirically proven that the quality of experience will alter the perceived value (Chen, 2007; Chen and Chen, 2010; Hume and Mort, 2008). The first proposition will be based on discussion done in this section.

Proposition 1: The tourists experience during a trip will positively influence the level of value creation for the services consumed.

\section{MODERATING EFFECT}

A moderator variable is a specification variable that systematically modifies either the strength and/or the form of the relationship between a set of predictor variables or criterion variables (Sharma et al., 1981; Prescott, 1986). The specification variables are categorized based on two dimension of characteristics, namely the relationship with the criterion variable and the interactions with predictor variable (Sharma et al., 1981; Prescott, 1986). Table 1 shows the classification of the specification variables. 
Table 1 Typology of specification variables (Sharma et al., 1981; Prescott, 1986)

\begin{tabular}{|c|c|c|}
\hline & $\begin{array}{l}\text { Related to criterion and/or } \\
\text { predictor }\end{array}$ & $\begin{array}{c}\text { Not related to criterion and } \\
\text { predictor }\end{array}$ \\
\hline $\begin{array}{l}\text { No interaction } \\
\text { with predictor }\end{array}$ & $\begin{array}{c}\text { Intervening, Exogenous, } \\
\text { Antecedent, Suppressor, } \\
\text { Predictor }\end{array}$ & $\begin{array}{c}\text { Moderator } \\
\text { (Homologizer) }\end{array}$ \\
\hline $\begin{array}{l}\text { Interaction with } \\
\text { predictor }\end{array}$ & $\begin{array}{c}\text { Moderator } \\
\text { (Quasi Moderator) }\end{array}$ & $\begin{array}{c}\text { Moderator } \\
\text { (Pure Moderator) }\end{array}$ \\
\hline
\end{tabular}

In this paper, the predictor variable is experience, the criterion variable is value, and the specification variable is service quality. Previously, many researchers have stressed on the relationship between service quality and value (Andreassen and Lindestad, 1998; Chen, 2008; Lai et al., 2009; Cronin et al., 2000; Bolton and Drew, 1991; Woodruff, 1997). However, in this paper, our focus is more on testing whether service quality plays a role in moderating the experience-value relationship. Hence, we consider service quality as a moderator. The review of literature suggested that there is a need to explore the relationship between experience and service quality. Even though there is no empirical research has been carried out on the interaction between experience and service quality, some researchers have suggested that the judgment on quality does not require customer experience (Caruana et al., 2000; Oliver, 1980). Therefore, based on this argument, the direct relationship between experience and service quality is not being supported. However, an indirect relationship may exist, because both service quality and experience contribute to the creation of value. After considering the interactions within these three constructs, we suggest that service quality as a quasi moderator in the relationship between experience and value.

Normally, service quality is a "must" element in luxury goods and services. However, service quality may be categorized as a value-added attribute when it comes with medium-priced goods and services market. Under these circumstances, the higher the service quality presented, the higher the value derived from experience. Alternatively, if the services come in the discounted or low -priced products, service quality may function as a delight attribute. In this market, consumer sensitivity on the pricing is great. To get the utility provided by prices, the consumers have to overlook the disutility inherent in quality as a sacrifice. Hence, presenting a high quality service concurrent with low-priced service in this market is expected to increase the value derived from experience. One can also views this analogy through Kano perspective. 
Consequently, we could say that experience influences value, and if the service quality is interacting with experience, it will modify the relationship form of experience and value. The effect of service quality on the relationship is expected to be significant, as past studies (Andreassen and Lindestad, 1998; Lai et al., 2009; Cronin et al., 2000) has proven that service quality have positively affect value. Based on the above arguments, the second proposition is being proposed.

Proposition 2: The services quality received during the trip is moderating the relationship between the tourist's experience and value.

\section{CONCLUSION AND IMPLICATIONS}

The discussion of the factors related to value creation can be seen from many perspectives. Adding new dimensions or modification of the interactions between dimensions may alter current understanding on value creation particularly in tourism context. The changed of role played by service quality, from predictor variable to moderator in the context of experience-value relationship, has open up a new area for future study. Although the relationship proposed in this study has not been empirically tested, the description of the interactions between these constructs will be significance in portraying the role of service quality as a moderator and how it is able to enhance the understanding on experience-value relationship. Moreover, the discussion in this paper will provide a basis in assisting service providers to design and serve their customers with high value services, which in turn, results in higher satisfaction level. Hence, this paper will be a good reference and could serve as a guideline for tourism service providers to improve and enhance their services in the future.

\section{REFERENCES}

Andreassen, T. W. \& Lindestad, B. (1998). Customer loyalty and complex services: the impact of corporate image on quality, customer satisfaction and loyalty for customers with varying degrees of service expertise. International Journal of Service Industry Management, 9(1), 7-23.

Asher, M. (1996). Managing quality in the service sector. London: Kogan Page.

Bitner, M. J. (1992). Servicescape: The impact of physical surrounddings on customers and employees. Journal of Marketing, 56(2), 57-71.

Bojanic, D. C. (1996). Consumer perceptions of price, value and satisfaction in the hotel industry: An exploratory study. Journal of Hospitality and Leisure Marketing, 4(1), 5-22. 
Bolton, R. N. \& Drew, J. H. (1991). A multistage model of customers' assessments of service quality and value. Journal of Consumer Research, 17(4), 375-384.

Buzzell, R. \& Gale, B. (1987). The PIMS principles. New York: The Free Press.

Caruana, A., Money, A. H., \& Berthon, P. R. (2000). Service quality and satisfaction the moderating role of value. European Journal of Marketing, 34(11/12), 1338-1353.

Chakrabarty, S., Whitten, D., \& Green, K. (2007). Understanding service quality and relationship quality in IS outsourcing: Client orientation \& promotion, project management effectiveness, and the task-technology-structure fit. Journal of Computer Information Systems, 48(2), 1-15.

Chang, T. \& Wildt, A. (1994). Price, product information, and purchase intention: an empirical study. Journal of Academic Marketing Science, 22(1), 16-27.

Chen, C. -F. (2007). Experience Quality, Perceived Value, Satisfaction and Behavioral Intentions for Heritage Tourists. The 13th Asia Pacific Management Conference, Melbourne: Australia.

Chen, C. F. (2008). Investigating structural relationships between service quality, perceived value, satisfaction, and behavioral intentions for air passengers: Evidence from Taiwan. Transportation Research Part A, 42(4), 709-717.

Chen, C. -F. \& Chen, F. -S. (2010). Experience quality, perceived value, satisfaction and behavioral Intentions for heritage tourists. Tourism Management, 31(1), 29-35.

Cronin, J. J., Brady, M. K., \& Hult, G. T. M. (2000). Assessing the effects of quality, value, and customer satisfaction on consumer behavioral intentions in service environments. Journal of Retailing, 76(2), 193-218.

Duman, T. \& Mattila, A. S. (2005). The role of affective factors on perceived cruise vacation value. Tourism Management, 26(3), 311-323.

Fiore, A. M. \& Kim, J. (2007). An integrative framework capturing experiential and utilitarian shopping experience. International Journal of Retail and Distribution Management, 35(6), 421-442.

Grönroos, C. (1990). Relationship approach to marketing in service contexts: the marketing and organizational behaviour interface. Journal of Business Research, 20(1), 3-11.

Gupta, S. \& Vajic, M. (1999). The contextual and dialectical nature of experiences. In Fitzsimmons and Fitzsimmons (Eds.), New Service Development (pp. 35-51). Thousand Oaks: Sage. 
Holbrook, M. B. (1994). The nature of customer value: an anthology of services in the consumption experience. In R. Rust and R. L. Oliver (Eds.), Service Quality: New Directions in Theory and Practice (pp. 21-71). Thousand Oaks: Sage Publications.

Horner, S. \& Swarbrooke, J. (1996). Marketing Tourism, Hospitality, and Leisure in Europe. London: International Thomson Business Press.

Hume, M. \& Mort, G. S. (2008). Satisfaction in performing arts: the role of value? European Journal of Marketing, 42(3/4), 311-326.

Kashyap, R. \& Bojanic, D. C. (2000). A structural analysis of value, quality, and price perceptions of business and leisure travelers. Journal of Travel Research, 39(1), 45-53.

Lai, F., Griffin, M., \& Babin, B. J. (2009). How quality, value, image, and satisfaction create loyalty at a Chinese telecom. Journal of Business Research, 62(10), 980-986.

McIntosh, R., Goeldner, C. \& Ritchie, J. (1995). Tourism: Principles, practices, philosophies (7th ed.). New York: John Wiley and Sons.

McDougall, G. H. \& Levesque, T. (2000). Customer satisfaction with service: Putting perceived value into the equation. Journal of Services Marketing, 14(5), 392-410.

Monroe, K. B. (1991). Pricing-Making profitable decision. New York: McGraw Hill.

Oh, H. (2000). The effect of brand class, brand awareness, and price on customer value and behavioral intentions. Journal of Hospitality and Tourism Research, 24(2), 136-162.

Oliver, R. L. (1980). A cognitive model of the antecedents and consequences of satisfaction decisions. Journal of Marketing Research, 17(November), 460-469.

Orsingher, C. \& Marzocchi, G. L. (2003). Hierarchical representation of satisfactory consumer service experience. International Journal of Service Industry Management, 14(2), 200-216.

Patterson, P. G. \& Spreng, R. A. (1997). Modelling the relationship between perceived value, satisfaction and repurchase intentions in a business-to-business, services context: an empirical examination. Journal of Service Industry Management, 8(5), 414-434.

Pine, B. J. \& Gilmore, J. H. (1999). The Experience Economy: work is Theatre and Every Business a Stage. Boston: Harvard Business School Press.

Prentice, R. C., Witt, S. F., \& Hamer, C. (1998). Tourism as experience. The case of heritage parks. Annals of Tourism Research, 25(1), 1-24. 
Prescott, J. E. (1986). Environments as Moderators of the Relationship between Strategy and Performance. The Academy of Management Journal, 29(2), 329-346.

Presbury, R., Fitzgerald, A. \& Chapman, R. (2005). Impediments to improvements in service quality in luxury hotels. Managing Service Quality, 15(4), 357-373.

Robinnette, S., Brand, C. \& Lenz, V. (2001). Emotion Marketing: The hallmark way of winning customer for life. New York: McGraw-Hill.

Ron, B. (1992). Value-chain assessment of travel experience. Cornell Hotel and Restaurant Administration Quarterly, 33(5), 41-49.

Ryu, K., Han, H., \& Kim, T. -H. (2008). The relationships among overall quick-casual restaurant image, perceived value, customer satisfaction, and behavioral intentions. International Journal of Hospitality Management, 27(3), 459-469.

Sandström, S., Edvardsson, B., Kristensson, P., \& Magmusson, P. (2008). Value in use through service experience. Managing Service Quality, 18(2), 112-126.

Sharma, S., Durand, R. M., \& Gur-Arie, O. (1981). Identification and analysis of moderator variables. Journal of Marketing Research, 18(3), 291-300.

UNWTO. (1995). Technical Manual No. 1, Concepts, Definitions and Classifications for Tourism Statistics. Madrid: UNWTO.

Vargo, S. L. \& Lusch, R. F. (2004). Evolving to a new dominant logic of marketing. Journal of Marketing, 68(1), 1-17.

Woodruff, R. (1997). Customer Value: The Next Source of Competitive Advantage. The Journal of the Academy of Marketing Science, 25(2), 139-153.

Zeitheml, V. A. (1988). Consumer perceptions of price quality, and value: A means-end model and synthesis of evidence. Journal of Marketing, 52(3), 2-22.

Zeithaml, V. A., Bitner, M. J., \& Gremler, D. D. (2006). Services marketing: Integrating Customer Focus Across the Firm (4th ed.). Boston: McGraw-Hill. 
